\title{
Antibody Titer
}

National Cancer Institute

\section{Source}

National Cancer Institute. Antibody Titer. NCI Thesaurus. Code C71683.

Concentration in serum of the antibody that recognizes a particular epitope expressed as the reciprocal of the highest serum dilution that produces the specific positive immunologic reaction in an appropriate test system. 